\title{
Dynamics of Corporate Dividend Policy under Hyperinflation and Dollarization: A Quantile Regression Approach
}

\author{
†Strike Mbulawa ${ }^{1}$, Francis Nathan Okurut ${ }^{2}$, Mogale Ntsosa ${ }^{3}$, Narain Sinha ${ }^{4}$ \\ ${ }^{1}$ Botho University, Department of Accounting and Finance \\ 2, 3,4 University of Botswana, Department of Economics
}

\begin{tabular}{l}
\hline ARTICLE INFO \\
\hline Article History \\
Received 26 October 2020; \\
Accepted 21 November \\
2020 \\
\hline JEL Classifications \\
G320 G350 G390
\end{tabular}
ABSTRACT Purpose:

Zimbabwe experienced hyperinflation (2000-2008) followed by dollarization from 2009 onwards which had implications on dividend policy. In this context, this study isolates the main determinants and examines their behaviour across the distribution of dividend policy.

Design/methodology/approach:

G320 G350 G390

The study employs quantile regression analysis and a sample of 30 firms listed on the Zimbabwe Stock Exchange (ZSE), covering the period 2000 to 2016 . The fixed effects (FE) analysis is applied as a base model.

Finding(s):

The most robust determinants are ownership structure, earnings per share (EPS) and taxation. In our context, results are more informative, than those based on FE analysis by showing the change in the impact of each explanatory variable across the distribution. EPS has a positive and significant impact on dividend policy throughout the distribution in both sample periods. Its effect increases in magnitude as firms move from low to high quantiles. The other variables are useful in explaining dividend policy at selected points of the

Keywords:

Dividend Policy,

Hyperinflation,

Dollarization,

Quantile Regression, Zimbabwe distribution. Thus, there is clear heterogeneity in the determinants of dividend policy.

Research limitations/implications:

The study shows the importance of developing dividend policy by focusing on the position of the firm on the distribution. Dividend policy should be developed in view of the earnings potential of the firm, ownership concentration and perceived changes in fiscal policy. A welldesigned policy should have a differentiated approach to influencing corporate dividends.

Originality/value:

This study enhances our understanding of dividend policy in unique markets. It confirms the applicability of dividend relevance theories. Furthermore, It shows that quantile analysis provides more reliable estimates than those obtained using standard panel data models.

\footnotetext{
1. Introduction

Zimbabwe's economy experiences structural changes between 1997 and 2019. This is triggered by both political and economic factors. In 1998, the government embarks on a reform to compulsorily acquire land from the white minority and give it to the landless black majority (Mandizha, 2014). Unbudgeted gratuities are paid to war veterans and the government supports the war in the Democratic Republic of Congo. The international community does not support such decisions and multilateral institutions like the International Monetary Fund (IMF), Africa Development Bank and the World Bank (WB) withdraw financial support. In response, the government prints money to finance its activities resulting in hyperinflation from 2000 to 2008 . The effects include: the worsening of the exchange rate, loss of import cover, fall in export revenue, negative gross domestic product (GDP) growth, deterioration in the balance of payments position and fall in production levels and a rise in unemployment. By the end of 2008 the official inflation rate reaches 231 million percent (Makochekanwa, 2007, Mandizha, 2014, Kararach Kadenge and Guvheya, 2010). During this period of high inflation, some firms pay dividends to retain investors. More so, the stock market provides a hedge against inflation and trading activities remain high (Jagongo and Mutswenje, 2014). The money market instruments perform badly due to high inflation and investors shift their portfolios to stock market related securities (Njanike, Katsuro, and Mudzura, 2009).
} 
However, inflation falls to single digits in February 2009 following the adoption of a multicurrency regime (Kanyenze, Chitambara and Tyson, 2017, Zhou and Zvoushe, 2012). The economy is partially dollarized, and the United States Dollar, South African Rand and Botswana Pula become legal tender. The speculative activities cease, and firms shift their focus to generating production profits (Sikwila, 2013, Njanike et al, 2009). The Reserve Bank of Zimbabwe (RBZ) loses its lender of last resort function which limits the availability of liquidity in the market. The market is still unstable which affects the level of dividends distributed by firms to shareholders as well. Hence formulating corporate dividend policy is still important for firm managers under dollarization period.

Previous studies (Edwards and Magendzo, 2001, Nor, 2012) on hyperinflation and dollarization fail to discuss these structural changes in view of corporate dividend policy. Understanding the determinants and dynamics of dividend policy in these periods adds to the current debate in corporate finance. Literature lacks studies that directly examine dividend dynamics in this context. This is despite the possibility that the predictive power of main dividend theories may be lost under these circumstances. Previous discussions are mainly based on standard panel data models which provide conclusions based on mean values of explanatory variables. They fail to fully exploit the critical information at different points of the distribution of dividend policy. In view of this, this study extends the current literature by employing quantile regression techniques to obtain useful information due to the presence of heterogeneity in the firms' dividend policy. The effect of each explanatory variable is sensitive to the position of the firm on the distribution of dividend policy. This is tested and confirmed using data for Zimbabwe firms.

The study offers some new insights by showing that there is clear heterogeneity in the determinants of dividend policy. The most robust determinants are ownership structure, earnings per share and taxation. In our context, results are more informative, than those based on fixed effects analysis by showing the change in the impact of each explanatory variable across the distribution. Earnings per share has a positive and significant impact on dividend policy throughout the distribution in both sample periods. Its effect increases in magnitude as firms move from low to high quantiles. The other variables are useful in explaining dividend policy at selected points of the distribution. Thus, quantile analysis provides more reliable estimates than those provided by standard panel data models. This study enhances our understanding of dividend policy in unique markets. It confirms the applicability of dividend relevance theories.

The rest of the study is organized as follows: section two summarizes the key theories underpinning this study and the main determinants of dividend policy, section three discusses the methodology applied in this study, section four discusses main results and section five concludes and provides policy implications.

\section{Literature Review}

This study is done under imperfect market conditions as such dividend policy affect firm value (Gordon, 1963, Lintner, 1962). It is underpinned by dividend relevance theories which are summarized as follows: the bird in hand theory, by Lintner and Gordon, shows that investors prefer current dividends which have low risk. They tend to discount future cashflows with a lower rate which increases the value of the firm. A firm that does not pay dividends experiences low firm value (Gordon, 1963, Lintner, 1962); the agency costs theory shows that the payment of dividends reduce the agency problem by removing excess cash which might be misused by managers (Easterbrook, 1984) and the clientele theory (Allen at el, 2000, Seida, 2002) shows that the payment of dividend attracts institutional investors due to low taxation. Investors' preference of dividend payments is determined by the level of taxation. Those in higher tax brackets prefer shares with low or no dividends while those in low tax brackets prefer cash dividends.

\section{Determinants of Dividend Policy \\ Past Dividends}

Thus far, literature is clear on the impact of previous dividend payouts on current dividend policy. Studies (Edmund, 2018, Mirbagherijam, 2014, Tran and Nguyen, 2014) have shown that past dividend payments are a good predictor of future dividend policies. Investors can use the payment of dividend as a signal for the future prospects of the firm. Firm managers are reluctant to reduce dividends payments even during inflationary periods. They continue to make disbursements to mimic good prospects for current and potential investors.

\section{Financial Leverage}

Highly leveraged firms (LEV) pay less dividends due to high debt service costs (Hosain, 2016, Edmund, 2018, Fliers, 2017). Such firms are exposed to the risk of bankruptcy. More dividends can be paid where a firm relies on other sources of cash flows (Nguyen et al, 2013, Ahmad and Javid, 2009). Payment of dividends may differ according to debt composition. Firms may be willing to acquire more debt to finance dividend payouts which acts as a signaling device to shareholders. However, some studies (Rizqia and Sumiati, 2013, Alzomaia and Al-Khadhiri, 2013) argue that financial leverage has no effect on dividend policy.

\section{Investment Outlays}

Previous studies (Al-Najjar and Belghitar, 2011, Ahmed and Javid, 2009) show that high investment expenditure (INV) reduces the likelihood of paying dividends. Firms with more investment opportunities may source external funding where access to financial markets is easy and they can still maintain high dividend payouts. Bildik, Fatemi, and Fooladi (2015) argue that large firms can still pay dividends in the absence of credible growth opportunities. 
Their study confirms the positive relationship between investment decisions and dividend policy. This is consistent with theoretical propositions (Adediran and Alade, 2013, Lahiri and Chakraborty, 2014) that firms can make investment and dividend decisions concurrently.

\section{Earnings per Share}

Literature confirms the linkages between earnings per share and dividend policy. For previous studies (Basse and Reddeman, 2011, Adediran and Alade, 2013, Bassey, Asinya, and Elizabeth, 2014, King'wara, 2015) show that high earnings per share (EPS) guarantee the payment of more dividends. Again, firms may not necessarily make huge dividend disbursements as they seek to retain funds for future use. Ahmed and Javid (2009) argue that though dividend policy is dependent on earnings per share (EPS) and past year's dividends, it is more sensitive to the former than the latter.

\section{Managerial Ownership}

The agency theory shows that managerial ownership is related to dividend policy. Studies (Björn and Lantz, 2016, Ahmed and Javid, 2009) show that more dividends are paid where managers seek to reward themselves using free cash flows. On the other hand, high managerial ownership (OWN1) may cause managers to postpone the payment of dividends and invest so as to increase the firm's future income generating capacity (Kania and Bacon, 2005, Mirza and Azfa, 2010, Bushra and Mirza, 2015). Low dividends in firms with high inside ownership are explained by the desire by management to increase the expected value of their stock options which they receive as compensation. However, studies like Arshad et al (2013) and Hosain (2016) show that in the case of Pakistan firms inside ownership and dividend policy have no relationship

\section{Institutional Ownership}

The presence of institutional shareholders brings discipline among managers who are deterred from overinvesting a firm's excess funds. Past studies (Bozec et al, 2010, Björn and Lantz, 2016) show that institutional ownership (OWN5) promotes the payment of dividends where a firm is at the high quantile of its growth opportunities. In this case the firm may be having more excess cashflows which are useful for rewarding owners. On the other hand, institutional shareholders may restrict payment of dividends and advocate for more money to be spent on growth opportunities (Kania and Bacon, 2005, Bushra and Mirza, 2015). However, Mossadak, Fontaine, and Khemakhem (2016) argue that institutional ownership has no effect on dividend policy.

\section{Taxation}

The taxation policy of the firm affects investor choices. Institutional investors and the elderly prefer dividend paying stocks since tax on dividends is low. Taxation (TP) reduces funds available for payment of dividends (Berzins, Bohren and Stacescu, 2017, Morck and Yeung, 2005). On the other hand, previous studies (Atia, 2017, Amidu and Abor, 2010) show that taxation has a positive relationship with dividend payout where firm managers have chosen a certain dividend policy, desire to use dividends as an investor retention strategy or have access to other financing alternatives. Chetty and Saez (2010) argue that corporate taxation does not distort the ability of a firm to pay more dividends in contrast to the agency cost theory. It has an insignificant effect on dividends (Gul et al, 2012, Khan, Jehan and Shah, 2017).

\section{Firm Size}

Large sized firms (SIZE2) pay more dividends as they are likely to be financially stable (Arshad et al, 2013, Michaely and Roberts, 2012). Similarly, Bildik et al (2015) show that large firms can still pay dividends in the absence of credible growth opportunities, but they have to be profitable (Kowalewski, Stetsyuk and Talavera, 2007). On the other hand, King'wara (2015) argues that large firms could have taken more debt to finance their current levels of growth. This reduces the ability to make dividend payments in the short term.

\section{Inflation and Money Supply}

Inflation (INFN) and money supply (MSP) are useful in controlling for hyperinflation and dollarization respectively as firms design their dividend policy. Basse and Reddeman (2011) argue that firms pay more dividends even when they are faced with high inflation. They can still rely on high nominal earnings. Firms are expected to have reduced dividends payout under hyperinflation (Elly and Hellen, 2013, Edmund, 2018) and more payouts during dollarization period. On the contrary, Mirbagherijam (2014) argues that dividends signal bad future prospects. Chronic high inflation results in a fall in the earnings as well as dividends. Pandey and Bhat (2004) show that money supply has a positive effect on dividend policy. On the contrary, Akyildirim et al (2013) supports the proposition that high money supply reduces the payment of dividends. Furthermore, Mambo (2012) argues that monetary policy activities have no effect on dividend policy. 


\section{Data, Methodology and Empirical Results}

\subsection{Model Specification}

Dividend policy (PR) is measured using dividend per share. The choice is determined by its usage in literature, diagnostic tests and giving of better results consistent with Zimbabwean context. The dependent variable, PR, is specified as function of the firm and macroeconomic variables and their expected signs are guided by literature. The generalized model is stated as:

Quant $_{\theta}\left(y_{i t} \mid x_{i t}\right)=\beta_{0}+\beta_{\theta f}$ firm $_{i t}+\beta_{\theta m}$ macro $_{i t}+\varepsilon_{i t}$

Where, Quant ${ }_{\theta}\left(y_{i t} \mid x_{i t}\right)$ is the $\boldsymbol{\theta t h}$ conditional quantile of $y_{i t}$, the dependent variable capturing corporate dividend policy, conditional on the vector of regressors $x_{i t}$ as represented by the firm and macro variables.

Quantile regression model (Koenker and Basset, 1978) is used to analyse the effects of each explanatory variable on corporate dividend policy in different quantiles. It helps in exploring, accurately, the determinants of dividend policy. This approach helps in understanding the effects of each variable by looking at the sign of the coefficient, size and level of significance across the distribution. It gives better results than those given by OLS models (Fattouh, Harris and Scaramozzino, 2008). The design matrix bootstrap method is used to estimate standard errors for coefficients (Buchinsky, 1998). Confidence intervals are constructed using the percentile method (Koenker and Hallock, 2001). Estimations are done using nine quantiles: 0.10, 0.20, 0.30, 0.40, 0.50, 0.60, 0.70, 0.80 and 0.90. The model estimated is specified as follows:

Quant $_{\theta}\left(y_{i t} \mid x_{i t}\right)=\beta_{0}+\beta_{1} F G_{i t}+\beta_{2} F L E V 6_{i t}+\beta_{3} O W N 5_{i t}+\beta_{4} I N F L N_{t}+\beta_{5} O W N 1_{i t}+\beta_{6} M S P_{t}+\beta_{7} E P S_{i t}+$ $\beta_{8} T P_{i t}+\beta_{9} I N V 1_{i t}+\beta_{10} S I Z E 2_{i t}+\varepsilon_{i t}$

The study also employs the fixed effects model to provide base results for comparison with quantile regression. Robust standard errors are employed. Potential endogeneity is tested by checking the robustness of estimates. This is done by removing or adding explanatory variables to see if results remain unchanged (See results in Tables 5 and 6 in the appendix). A sample of 30 non-financial firms, is used, that are listed on the ZSE, giving a total of 510 firm years. Annual data on firm characteristics and macroeconomic variables is extracted from financial statements of firms and WB (2017) respectively. All variables, used in this study, are defined in Table 1.

*Table 1: Variables Definitions: Dividend Decisions

\begin{tabular}{|c|c|c|}
\hline Variable & Definition & References \\
\hline Dividend policy (PR1) & Dividend paid/Total Shares & $\begin{array}{l}\text { Huda and Abdullah, 2013, Adediran and Alade, } \\
\text { 2013, Björn and Lantz, 2016 }\end{array}$ \\
\hline Firm growth $(\mathrm{FG})$ & $\begin{array}{l}\text { \% Change in total sales } \\
((\text { Current year Sales-Previous } \\
\text { year Sales }) / \text { Previous Year } \\
\text { Sales })\end{array}$ & $\begin{array}{l}\text { Chen and Dhiensiri, 2009, Kania and Bacon, 2005, } \\
\text { Al-Kuwari 2009, Edmund, } 2018\end{array}$ \\
\hline Leverage (Flev 6) & Total debt/equity & $\begin{array}{l}\text { Ahmad and Javid, 2009 ; Huda and Abdullah, 2013, } \\
\text { Al-Kuwari 2009; Rizqia and Sumiati, 2013, } \\
\text { Mutenheri, 2003, Arshad et al, 2013, Edmund, 2018 }\end{array}$ \\
\hline $\begin{array}{l}\text { Investment decisions } \\
\text { (INV1) }\end{array}$ & $\begin{array}{l}\text { Net Fixed Assets (Total } \\
\text { Fixed } \\
\text { Liabilities- } \\
\text { Depreciation)/Total Assets }\end{array}$ & Mutenheri, 2003 \\
\hline Inflation (INFLN) & $\begin{array}{l}\text { Annual Inflation Rate divided } \\
\text { by } 100\end{array}$ & Elly and Hellen, 2013, Edmund, 2018 \\
\hline Ownership & $\begin{array}{l}\text { Management } \\
\text { shareholding/Total shares }\end{array}$ & $\begin{array}{l}\text { Chen and Dhiensiri, 2009, Kania and Bacon, 2005, } \\
\text { Rizqia and Sumiati, 2013, Mutenheri, } 2003\end{array}$ \\
\hline $\begin{array}{l}\text { Institutional Ownership } \\
\text { (OWN5) }\end{array}$ & $\begin{array}{l}\text { Total shares owned by } \\
\text { Institutional Investors/Total } \\
\text { Shares }\end{array}$ & Kania and Bacon, 2005, Mutenheri, 2003 \\
\hline Firm size (SIZE2) & Log of Total Assets & $\begin{array}{l}\text { Ahmad and Javid, 2009; Arif and Akbarshah, 2013; } \\
\text { King'wara, 2015, Arshad et al, } 2013\end{array}$ \\
\hline Money Supply (MSP) & M2 over GDP, as a decimal & Elly and Hellen, 2013 \\
\hline Earnings per Share (EPS) & $\begin{array}{l}\text { Earnings over total shares } \\
\text { outstanding }\end{array}$ & Adediran and Alade, 2013, Tran and Nguyen, 2014 \\
\hline Taxation $(\mathrm{TP})$ & Tax paid/Operating income & Arif and Akbarshah, 2013; Chetty and Saez, 2010. \\
\hline
\end{tabular}

DOI: $10.25103 /$ ijbesar.133.06 
*The Table contains definitions of main variables as they are applied in this study.

\section{Results and Discussion}

\subsection{Diagnostic Tests and Descriptive Statistics}

The study employs Levin, Lin and Chu (LLC) and Im, Pesaran and Shin (IPS) to test for unit root at 5\% level of significance and results show that all variables are stationary at levels. The study considers multicollinearity using Pearson correlation matrix. Correlation coefficients are mostly less than 0.5 which implies that there is limited multicollinearity between any pair of variables. Thus, all the variables could be used in the same model without giving spurious results.

All the variables (Table 2) are positively and highly skewed except for the measure of investment decisions. Variables in the analysis are leptokurtic with a measure of kurtosis higher than 3. The study shows that the average dividend per share is US\$0.025. The average firm growth rate is $11.9 \%$ and firms are not highly geared since the average level is slightly above 50\%. The average inflation rate is $136190.1 \%$ during the period of analysis. Management hold about $8.6 \%$ of shares while institutional shareholders hold $74.4 \%$ of shares on average. The average of money supply is $55 \%$ of GDP for Zimbabwe. Earnings per share are US\$0.041 while the tax paid is around $12 \%$ on average. The level of investment fell, on average, by about $16 \%$, during the period of analysis.

Table 2: Descriptive Statistics

\begin{tabular}{|l|l|l|l|l|l|l|l|l|l|l|l|}
\hline & PR1 & FG & FLEV6 & INFLN & OWN1 & SIZE2 & MSP & EPS & TP & INV1 & $\begin{array}{l}\text { OWN } \\
5\end{array}$ \\
\hline Mean & 0.03 & 0.12 & 0.52 & 136190.1 & 0.09 & 17.91 & 0.55 & 0.04 & 0.12 & -0.16 & 0.74 \\
\hline Median & 0.01 & 0.01 & 0.36 & 0.55 & 0.04 & 17.88 & 0.45 & 0.02 & 0.11 & -0.13 & 0.83 \\
\hline Max & 0.43 & 4.53 & 6.63 & 2310000 & 1.44 & 20.57 & 1.52 & 0.41 & 0.63 & 0.70 & 8.72 \\
\hline Min & 0.00 & -0.86 & -0.90 & -0.02 & $3.0 \mathrm{e}-05$ & 15.38 & 0.27 & -0.05 & 0.00 & -1.95 & 0.04 \\
\hline S. Dev. & 0.04 & 0.53 & 0.59 & 544554.7 & 0.13 & 0.94 & 0.28 & 0.06 & 0.08 & 0.34 & 0.45 \\
\hline Skew & 4.57 & 2.39 & 4.40 & 3.75 & 3.95 & 0.46 & 2.41 & 3.14 & 1.70 & -0.98 & 10.86 \\
\hline Kur & 36.75 & 14.85 & 36.78 & 15.03 & 28.12 & 3.50 & 9.02 & 15.25 & 9.72 & 5.78 & 197.7 \\
\hline Obs & 509 & 509 & 509 & 509 & 509 & 509 & 509 & 509 & 509 & 509 & 509 \\
\hline
\end{tabular}

Notes: obs=Observations, kur=kurtosis, skew=skewness, min=minimum, s.dev=standard deviation \& min=maximum. All variables defined in Table 1 .

\subsection{Quantile Regression Analysis}

Table 3 and Figure 1 show results during hyperinflation period while Table 4 and Figure 2 show results under dollarization. The most robust determinants of corporate dividend policy, in both periods, are ownership structure variables, earnings per share and taxation. Findings show that investment decisions, firm growth (Edmund, 2018), leverage (Rizqia and Sumiati, 2013, Alzomaia and Al-Khadhiri, 2013) and inflation are insignificant under hyperinflation. Inflation, money supply and size are not important in explaining dividend policy under dollarization which is consistent with previous studies (Elly and Hellen, 2013, King'wara, 2015, Mohsin and Ashraf, 2011). 
Table 3: Quantile Regression Model: PR1 as Dep. Var (2000-2008)

\begin{tabular}{|c|c|c|c|c|c|c|c|c|c|c|}
\hline Variable & FE & $10^{\text {th }}$ Quant & $20^{\text {th }}$ Quant & $30^{\text {th }}$ Quant & $40^{\text {th }}$ Quant & $50^{\text {th }}$ Quant & $60^{\text {th }}$ Quant & $70^{\text {th }}$ Quant & $\begin{array}{l}80^{\text {th }} \\
\text { Quant }\end{array}$ & $90^{\text {th }}$ Quant \\
\hline $\mathrm{FG}$ & $-0.0021 * * *$ & -0.0012 & -0.0018 & -0.0012 & $-6.95 \mathrm{e}-06$ & 0.0004 & 0.0001 & 0.0016 & 0.0010 & -0.0014 \\
\hline FLEV6 & $-0.0013^{*} *$ & 0.0011 & 0.0012 & 0.0010 & 0.0016 & 0.0015 & 0.0020 & 0.0010 & 0.0024 & 0.0011 \\
\hline INFLN & $-5.03 \mathrm{E}-10$ & $-9.97 e-11$ & $-6.25 \mathrm{e}-10$ & $-4.09 \mathrm{e}-10$ & $-7.37 \mathrm{e}-10$ & $-6.69 \mathrm{e}-10$ & $-7.73 \mathrm{e}-10$ & $-1.94 \mathrm{e}-09$ & $-2.05 \mathrm{e}-09$ & $-1.73 \mathrm{e}-09$ \\
\hline OWN1 & $0.0505 * * *$ & $0.0248 * * *$ & $0.0249 * * *$ & $0.0216^{* * *}$ & $0.0219^{* * * *}$ & $0.0223 * * *$ & $0.0152^{* * * *}$ & $0.0252 * * *$ & $0.0393 * * *$ & $0.0491 * * *$ \\
\hline SIZE2 & -0.0012 & $-3.71 \mathrm{e}-05$ & $-8.32 \mathrm{e}-05$ & $-6.91 \mathrm{e}-05$ & -0.0001 & -0.0001 & $-4.62 \mathrm{e}-05$ & $7.48 \mathrm{e}-05$ & 0.0003 & $0.0012^{*} *$ \\
\hline MSP & -0.0001 & -0.0025 & -0.0010 & -0.0014 & $8.84 \mathrm{e}-06$ & 0.0005 & 0.0002 & -0.0010 & -0.0049 & $-0.0096 * *$ \\
\hline EPS & $0.0701 * * *$ & $0.1230^{* * * *}$ & $0.1693 * * *$ & $0.2538 * * *$ & 0.3163 **** & $0.3662 * * *$ & $0.4470^{* * * *}$ & $0.5142^{*} * * *$ & $0.6830^{* * * *}$ & $1.0281 * * * *$ \\
\hline INV1 & 0.0016 & 0.0008 & 0.0012 & 0.0006 & 0.0006 & $-7.59 \mathrm{e}-06$ & -0.00028 & 0.0014 & -0.0006 & 0.0023 \\
\hline OWN5 & $-0.0037 *$ & 0.0011 & 0.0010 & 0.0011 & 0.0015 & 0.0011 & -0.0001 & 0.0006 & -0.0023 & $-0.0149 *$ \\
\hline $\mathrm{R}^{2}$ & 0.79 & & & & & & & & & \\
\hline F-Test & $21.69^{* * * *}$ & & & & & & & & & \\
\hline DW & 1.98 & & & & & & & & & \\
\hline
\end{tabular}

**** significant at 1\%; ** significant at 5\%; *significant at 10\%. Definitions of all variables are in Table 1. The Fixed Effects (FE) provides base results in the first column. The table provides results for 9 quantiles for the period 2000-2008. There is a total of 270 observations. Bootstrap method is used to estimate standard errors for coefficients using quantile analysis. The dependent variable is dividend per share (PR1). Results form quantile regression for OWN1, EPS, TP \& OWN5 are consistent with those using FE model. 
Figure1 presents quantile process estimates and definitions of all variables are in Table 1. The Fixed Effects (FE) provides base results in the first column. The table provides results for 9 quantiles for the period 2000-2008. There is a total of 270 observations. Bootstrap method is used to estimate standard errors for coefficients using quantile analysis. The dependent variable is dividend per share (PR1). Results from quantile regression for OWN1, EPS, TP E OWN5 are consistent with those using FE model.

FG
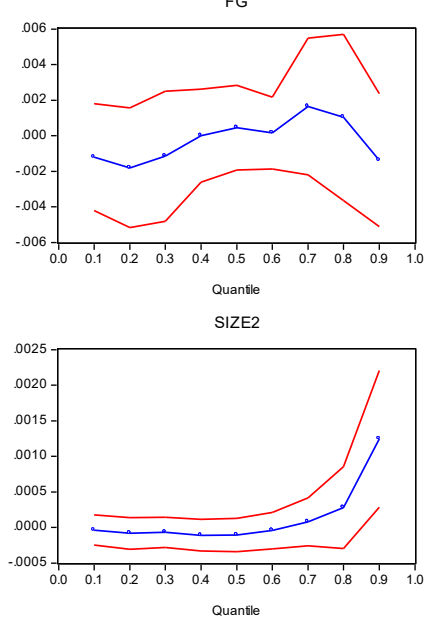

INV1

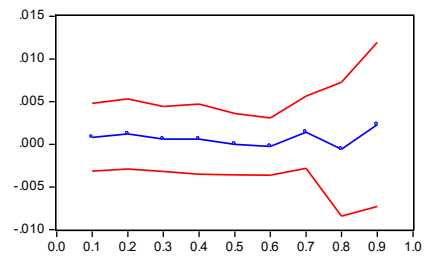

Quantile
Quantile Process Estimates
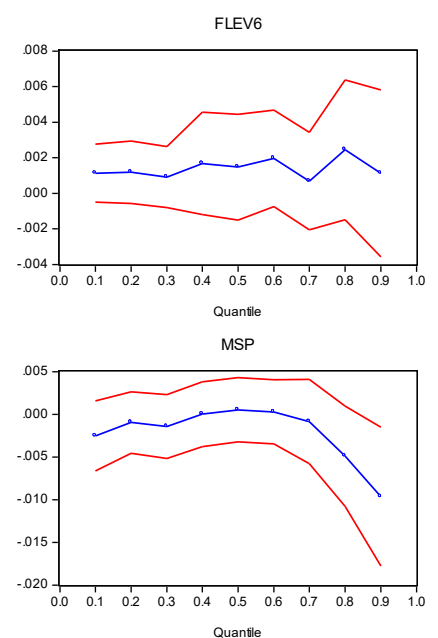

OWN5

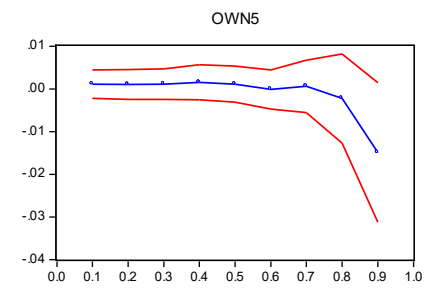

Quantile
INFLN
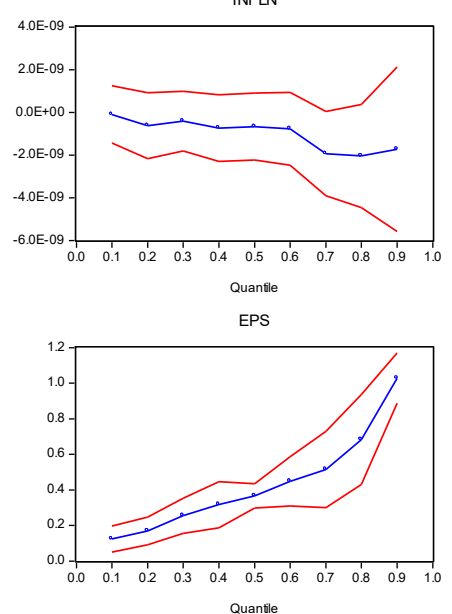

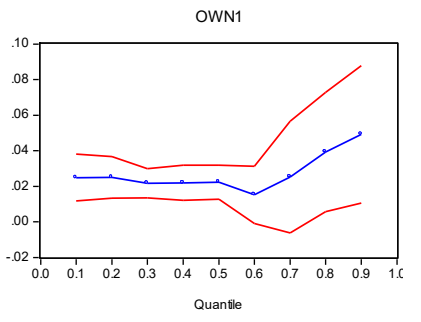

TP

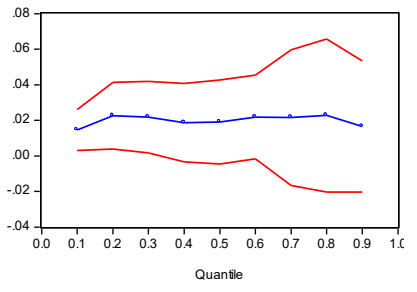

Figure 1: Determinants of Dividend Policy 2000 - 2008 
Table 4: Quantile Regression Model: PR1 as Dep. Var (2009-2016)

\begin{tabular}{|c|c|c|c|c|c|c|c|c|c|c|}
\hline Variable & $\mathrm{FE}$ & $10^{\text {th }}$ Quant & $20^{\text {th }}$ Quant & $30^{\text {th }}$ Quant & $40^{\text {th }}$ Quant & $50^{\text {th }}$ Quant & $60^{\text {th }}$ Quant & $70^{\text {th }}$ Quant & $80^{\text {th }}$ Quant & $90^{\text {th }}$ Quant \\
\hline $\mathrm{FG}$ & $-0.0010^{*} * *$ & 0.0004 & 0.0005 & 0.0010 & $-5.56 \mathrm{e}-05$ & $-5.30 \mathrm{e}-05$ & -0.0013 & -0.0016 & -0.0030 & $-0.0068^{* *}$ \\
\hline FLEV6 & $0.0016^{*}$ & 0.0002 & $-4.04 \mathrm{e}-05$ & -0.003 & -0.003 & 0.0002 & $-9.23 \mathrm{e}-05$ & $0.0050^{* * * *}$ & $0.0051 * * *$ & $0.0042^{* * * *}$ \\
\hline INFLN & 0.0049 & -0.0175 & -0.0060 & 0.0011 & 0.0047 & 0.0006 & 0.0117 & 0.0186 & 0.0805 & 0.017 \\
\hline OWN1 & $0.0389 * * *$ & 0.0147 & 0.0186 & $0.0281 * * *$ & $0.0334 * * *$ & $0.0358 * * *$ & $0.0436 * * *$ & $0.0591 * * * *$ & $0.0930 * * *$ & $0.1359 * * *$ \\
\hline SIZE2 & $-0.0029^{*}$ & $5.95 \mathrm{e}-05$ & $-7.78 \mathrm{e}-06$ & $5.98 \mathrm{e}-06$ & 0.0001 & 0.0001 & $1.45 \mathrm{e}-05$ & 0.0002 & 0.0005 & 0.0015 \\
\hline MSP & 0.0029 & -0.0043 & 0.0002 & 0.0008 & -0.0016 & 0.0016 & 0.0172 & 0.0066 & 0.0015 & 0.0537 \\
\hline EPS & $0.0492^{*}$ & $0.2017 * * *$ & $0.2396 * * *$ & $0.2683 * * *$ & $0.2690^{* * * *}$ & $0.2892 * * *$ & $0.3346 * * *$ & $0.4131 * * *$ & $0.4678 * * *$ & $0.6606^{* * * *}$ \\
\hline $\mathrm{TP}$ & 0.0033 & -0.0023 & -0.0011 & -0.0019 & -0.0001 & $3.77 \mathrm{e}-05$ & 0.0002 & -0.0040 & -0.0133 & $-0.0453 * *$ \\
\hline INV1 & $0.0042^{* *}$ & 0.0016 & 0.0010 & 0.0018 & $0.0025^{*}$ & 0.0023 & $0.0048 * *$ & $0.0050^{*}$ & 0.0064 & 0.0127 \\
\hline OWN5 & $0.0046^{* * *}$ & 0.0008 & 0.0009 & 0.0008 & -0.0003 & -0.0015 & $-0.0053^{*}$ & -0.0081 & -0.0101 & $-0.0347 * * * *$ \\
\hline $\mathrm{R}^{2}$ & 0.83 & & & & & & & & & \\
\hline F-Test & $24.83 * * *$ & & & & & & & & & \\
\hline DW & 2.02 & & & & & & & & & \\
\hline
\end{tabular}

*** significant at 1\%; ** significant at 5\%; *significant at 10\%. Definitions of all variables are in Table 1. The Fixed Effects (FE) provides base results in the first column. The table provides results for 9 quantiles for the period 2009-2016. There is a total of 239 observations. Bootstrap method is used to estimate standard errors for coefficients using quantile analysis. The dependent variable is dividend per share (PRI). Results from quantile regression for FG, FLEV6, OWN1, EPS E INVI are consistent with those using FE model. 
Figure1 presents quantile process estimates and definitions of all variables are in Table 1.The Fixed Effects (FE) provides base results in the first column. The table provides results for 9 quantiles for the period 2009-2016. There a total of 239 observations. Bootstrap method is used to estimate standard errors for coefficients using quantile analysis. The dependent variable is dividend per share (PR1). Results from quantile regression for FG, FLEV6, OWN1, EPS \& INV1 are consistent with those using FE model.
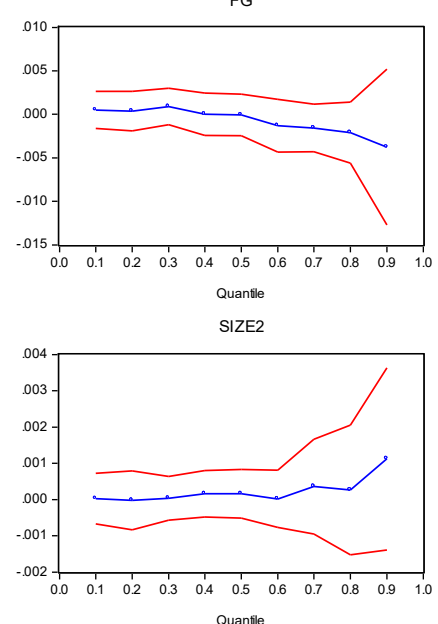

INV1

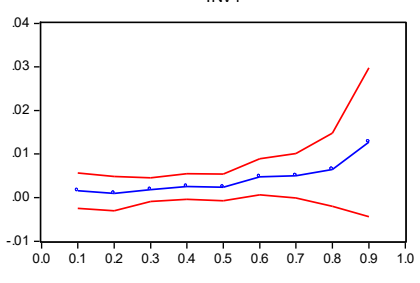

Quantile Process Estimates

FLEV6
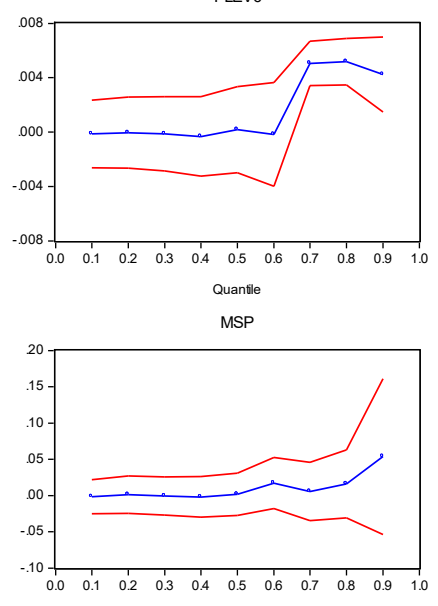

Quantile

OWN5

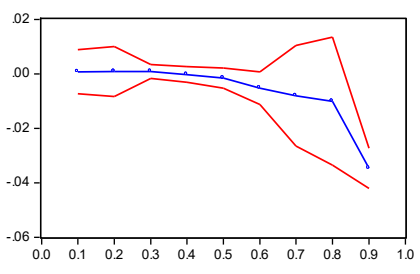

INFLN

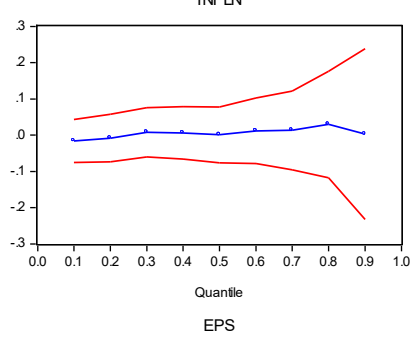

EPS

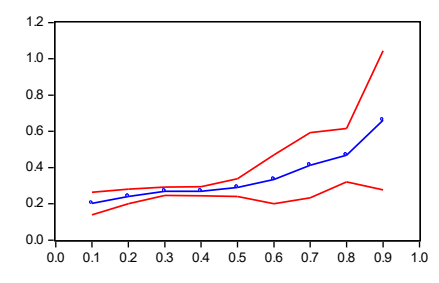

Quantle

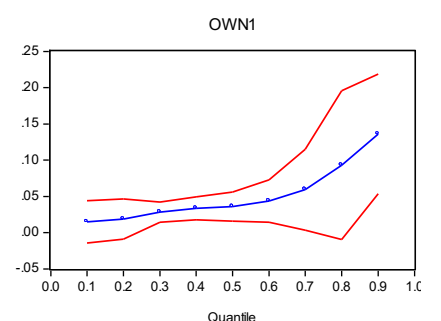

Quantile

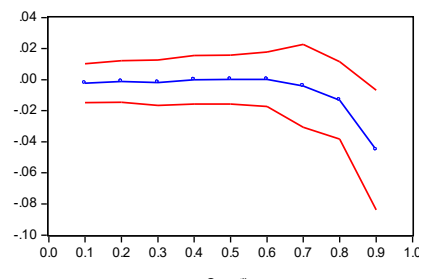

Quantle

Figure 2: Determinants of Dividend Policy 2009 - 2016

The study shows that insider ownership has a positive effect on dividend policy which is consistent with the results based on the FE model. However, quantile regression shows clear variations in the magnitude of coefficients as firms move from low to high quantiles. Under hyperinflation, there is evidence of managerial entrenchment throughout the distribution. Under dollarization, insider ownership is important from $30^{\text {th }}$ quantile onwards. In both periods, the effect of inside ownership increases as firms move to higher levels of the distribution of dividend policy. Findings are consistent with past studies (Mossadak, Fontaine and Khemakhem, 2016, Gowri and Saravanan, 2016) which support strong managerial entrenchment as firms move towards higher levels of dividend policy.

Institutional ownership has a negative effect in both structural periods. Firms with high institutional ownership can successfully reduce the payment of dividends. This is consistent with previous studies (Reyna, 2017, Yusof and Ismail, 2016). This study shows that their monitoring role is effective for firms with high dividend policy or payout ratios. The significance of institutional ownership is in the $90^{\text {th }}$ quantile and starts from $60^{\text {th }}$ quantile under hyperinflation and dollarization respectively.

Under hyperinflation, expansionary monetary policy reduces the payment of dividend at the higher level of the distribution of dividend policy. This is consistent with Akyildirim et al, (2013) who suggest that high money supply is inflationary which further erodes cashflows meant for dividend payouts. Under dollarization, the effect of money supply is insignificant. Consistent with Mohsin and Ashraf (2011), the results show that expansionary monetary policy has no effect on dividend policy. Firms have alternative sources of finance to improve dividend payouts.

The positive impact of earnings per share differs across the conditional distribution of firms' dividend policy in both periods. The magnitude of the coefficient increases as firms move from lower to higher quantiles. This shows the persistent impact of earnings per share on dividend payout as predicted by theory. Thus, at higher levels of dividend policy, firms with higher earnings pay more dividends as supported by previous studies (King'wara, 2015, Bassey et al, 2014).

Taxation has a positive impact on dividend payout at lower quantiles, under hyperinflation upto the $60^{\text {th }}$ quantile. The positive effect is consistent with past studies (Atia, 2017, Amidu and Abor, 2010). This may indicate their desire to maintain a certain level of dividend policy and more so their ability to source funding elsewhere. At high levels of

+Corresponding Author: Strike Mbulawa

e-mail: smint50000@gmail.com

DOI: 10.25103/ijbesar.133.06 
dividend policy, profitable firms are not considering the effects of taxation when deciding to pay or not to pay dividends. However, under dollarization, taxation has a negative effect within the $90^{\text {th }}$ quantile. In our context, this shows that firms face the real burden of taxation at higher quantiles considering that the economy is using a stable currency. Previous studies (Arif and Akbarshah, 2013, Chuang et al, 2018) show that higher taxation adversely affects remuneration for shareholders.

The study shows that firm size explains dividend policy under hyperinflation and it is significant in the $90^{\text {th }}$ quantile. Thus, at higher levels of dividend policy, larger firms are likely to increase their dividend payout ratio and move towards the upper levels. This confirms the argument by Arif and Akbarshah (2013) that large firms have more access to debts market and hence experience fewer external constraints. Dividend policy is not sensitive to firm size under dollarization.

Investment decisions are important under dollarization and have a positive effect between the $40^{\text {th }}$ and $70^{\text {th }}$ quantiles only. The positive effect is consistent with Bildik et al (2015). Thus, policy makers' focus should be on firms that are within this range since they are likely to withstand any financial constraints within the economy and continue to pay dividends. Such firms can access alternative sources of investment funds like debt and retained profits. Our results suggest that a study like Lestari (2018), showing that investment has no effect on dividend policy may have analysed behavior of firms at the lowest parts of the distribution.

Consistent with past studies (Bushra and Mirza, 2015, Cristea and Cristea, 2017), this study shows that firm growth has a negative effect on dividend policy under dollarization. Thus, firms at the high level of the distribution reduce payment of dividend to free up funds for taking up new opportunities. More so, the study shows that leverage has a positive effect on dividend policy from the $70^{\text {th }}$ quantile. This is consistent with past studies (Thirumagal and Vasantha, 2017, Gowri and Saravanan, 2016) which show that firms are willing to acquire more debt to finance dividend payouts which acts as a signaling device to shareholders. This behavior is expected where firms are not afraid of the risk of bankruptcy as they are exposed to more debt.

\section{Conclusion}

This study contributes to corporate finance literature by examining dynamics of dividend policy under unique market conditions. It identifies the major determinants and examines their contribution at different positions of the firm's dividend distribution. By using quantile regression analysis, the study brings useful information which is critical for policy making. The study confirms the importance of dividend relevance theories by showing role played by institutional shareholders, managerial share ownership and taxation. The results are more informative than those from previous studies which are based on OLS methodology. They indicate the points, on the distribution, at which key variables affect dividend policy. For example, under hyperinflation firm size, money supply and institutional ownership have a positive, negative and negative effect, respectively, on dividend policy at $90^{\text {th }}$ quantile. Earnings per share and inside ownership are positive and significant throughout the distribution while taxation has a positive effect at lower quantiles. Under dollarization, the behavior of institutional ownership and firm growth suggests a non-linear relationship with dividend policy since the sign of the parameter changes from positive to negative. Insider ownership is significant from the $30^{\text {th }}$ quantile onwards. Other variables like leverage, taxation and investment decisions are important at specific points on the distribution. These results provide a firm foundation for understanding dividend policy in markets under unique conditions. They show the importance of developing policies by focusing on the position of the firm on the distribution of dividend policy. A dividend policy that focus on reducing informational inefficiencies would be desirable for the Zimbabwean market.

\section{Acknowledgement}

This work has been extracted from a PhD thesis submitted to the University of Botswana. I thank all my fellow students and staff members in the Department of Economics for making valuable comments to this work on earlier drafts.

\section{Funding}

No funding was received.

\section{Declaration of conflicting interests}

The authors declare no conflict of interest with respect to the research, authorship, and/or publication of this article. 


\section{References}

Adediran, S.A. and Alade, S.O., 2013. Dividend policy and corporate performance in Nigeria. American Journal of Social and Management Sciences, 4(2), pp.71-77.

Ahmed, H. and Javid, A.Y., 2009. Dynamics and determinants of dividend policy in Pakistan (evidence from Karachi stock exchange non-financial listed firms). 25. pp. 148-171.

Akyildirim, E., Güney, I.E., Rochet, J.C. and Soner, H.M., 2014. Optimal dividend policy with random interest rates. Journal of Mathematical Economics, 51, pp.93-101.

Al-Kuwari, D., 2009. Determinants of the dividend policy of companies listed on emerging stock exchanges: the case of the Gulf Cooperation Council (GCC) countries. Global Economy \& Finance Journal, 2(2), pp.38-63.

Allen, F., Bernardo, A.E. and Welch, I., 2000. A theory of dividends based on tax clienteles. The Journal of Finance, 55(6), pp.2499-2536.

Al-Najjar, B. and Belghitar, Y., 2011. Corporate cash holdings and dividend payments: Evidence from simultaneous analysis. Managerial and Decision Economics, 32(4), pp.231-241.

Alzomaia, T. and Al-Khadhiri, A. 2013. Determinants of dividend policy: The evidence from Saudi Arabia. International Journal of Business and Social Science, 4(1), pp. 181-192.

Amidu, M. and Abor, J. 2006. Determinants of dividend payout ratios in Ghana. The Journal of Risk Finance, 7(2), pp. 136-145.

Arif, A. and Akbarshah, F., 2013. Determinants of dividend policy: a sectoral analysis from Pakistan. International Journal of Business and Behavioral Sciences, 3(9), pp.16-33.

Arshad, Z., Akram, Y., Amjad, M. and Usman, M., 2013. Ownership structure and dividend policy. Interdisciplinary Journal of Contemporary Research in Business, 5(3), pp.378-401.

Atia, O., 2017. Cash dividend policy and firm risk: UK evidence (Doctoral dissertation, University of Salford).

Basse, T. and Reddemann, S., 2011. Inflation and the dividend policy of US firms. Managerial Finance, 37(1), pp. 34-46.

Bassey, N.E., Asinya, F.A. and Elizabeth, A., 2014. Determinants of Dividend Payout of Financial Institutions in

Nigeria: A Study of Selected Commercial Banks. Research Journal of Finance and Accounting, 5(7), pp. 74-80

Berzins, J, Bohren, O. and Stacescu, B. 2017. Dividend, Taxes and Agency Costs. Center for Corporate Governance Research, Working 2/2013.

Bildik, R., Fatemi, A. and Fooladi, I., 2015. Global dividend payout patterns: The US and the rest of the world and the effect of financial crisis. Global Finance Journal, 28, pp.38-67.

Björn, L. and Lantz, E, C., 2016. Ownership structure's effect on dividend policy: Evidence from publicly listed Swedish firms. Available at: https://umu.diva-portal.org/smash/get/diva2:947008/FULLTEXTo1.pdf (Accessed 17 July 2019).

Bozec, Y., Francoeur, C., Labelle, R. and Okoudjou, V., 2010. Institutional Investors and Governance. French Journal of Corporate Governance, 7, pp.83-104.

Buchinsky, M., 1998. Recent advances in quantile regression models: a practical guideline for empirical research. Journal of Human Resources, pp.88-126.

Bushra, A. and Mirza, N., 2015. The determinants of corporate dividend policy in Pakistan. The Lahore Journal of Economics, 20(2), pp.77-98.

Chen, J. and Dhiensiri, N., 2009. Determinants of dividend policy: The evidence from New Zealand. International Research Journal of Finance and Economics, 34, pp. 18-28.

Chetty, R. and Saez, E., 2010. Dividend and corporate taxation in an agency model of the firm. American Economic Journal: Economic Policy, 2(3), pp.1-31.

Chuang, S.T., Chen, Y.H., Lin, C.C. and Lee, W.C., 2018. The Impact of Tax Deduction Ratio Reduction on Dividend Payouts under the Integrated Tax System: Evidence from Taiwan. International Journal of Financial Research, 9(3), pp.26-35.

Easterbrook, F.H., 1984. Two agency-cost explanations of dividends. The American economic review, 74(4), pp.650-659.

Edmund, N. K. N. 2018. Determinants of Dividend Policy among Banks Listed on the Ghana. Journal of Business and Financial Affairs, 7(1), pp. 2-7

Edwards, S. and Magendzo, I.I., 2001. Dollarization, inflation and growth (No. w8671). National Bureau of Economic Research.

Elly, O.D. and Hellen, K.W., 2013. Relationship between inflation and dividend payout for companies listed at the Nairobi Securities Exchange. International Journal of Education and Research, 1(6), pp.1-8.

Fattouh, B., Harris, L. and Scaramozzino, P., 2008. Non-linearity in the determinants of capital structure: evidence from UK firms. Empirical Economics, 34(3), pp.417-438.

Fliers, P., 2017. Dividend smoothing, financial flexibility and capital structure. Financial Flexibility and Capital Structure (May 24, 2017). Available at http://dx.doi.org/10.2139/ssrn.2821657 [Accessed 20 May 2019]

Gordon, M.J., 1963. Optimal investment and financing policy. The Journal of Finance, 18(2), pp.264-272.

Gowri, K. and Saravanan, R., 2016. Determinants of Dividend Policy of Select Companies in Indian Cement Industrya Structural Equation Modeling. International Journal of Advanced Research in Management and Social Sciences, 5(7), pp. 161-173

Gul, S., Khan, M.B., Ahmad, B., Rehman, S.U. and Shah, M., 2012. Taxes and dividend policy (The case of Pakistan). Research Journal of Finance and Accounting, 3(10), pp.115-121. 
Hosain, Z., 2016. Determinants of the Dividend Payout Policy: A Study on Listed Private Commercial Banks of Dhaka Stock Exchange Limited in Bangladesh. IOSR Journal of Economics and Finance, 7(5), pp.1-10.

Huda, N. and Abdullah, M, N. (2013). 'Relationship between ownership structure and dividend policy: Empirical evidence from Chittagong Stock Exchange', Asian Business Research Conference, Dhaka, Bangladesh, 20-2 1 December.

Jagongo, A. and Mutswenje, V.S., 2014. Factors Influencing Investment Decisions at the Nairobi Stock Exchange. International Journal of Humanities and Social Science, 4(4), pp. 11-14.

Kania, S, L. and Bacon, F, W. 2005. What factors motivate the corporate dividend decision? ASBBS E-Journal, 1(1), pp. 97-107

Kanyenze, G., Chitambara, P. and Tyson, J., 2017. The Outlook for the Zimbabwean Economy. SET. UKAID. September.

Kararach, G, Kadenge, P. and Guvheya, G., 2010. Currency reforms in Zimbabwe: An analysis of Possible Currency Regimes', The African Capacity Building Foundation, Occassional paper 10 (2010), pp 1-41.

Khan, N.U., Jehan, Q.U.A.S. and Shah, A., 2017. Impact of taxation on dividend policy: Evidence from Pakistan. Research in international business and Finance, 42, pp.365-375.

King'wara, R., 2015. Determinants of dividend payout ratios in Kenya. Research Journal of Finance and Accounting, 6(1), pp.48-51.

Koenker, R. and Basset, G. 1978. Regression quantiles. Econometrica, 46(1), pp. 33-50

Koenker, R. and Hallock, K.F., 2001. Quantile regression. Journal of Economic Perspectives, 15(4), pp.143-156.

Kowalewski, O., Stetsyuk, I. and Talavera, O., 2007. Do corporate governance and ownership determine dividend policy in Poland? Available at SSRN 1133013. Bank i Kredyt, (11-12), pp. 60-86.

Lahiri, P. and Chakraborty, I., 2014. Explaining dividend gap between R\&D and non-R\&D Indian companies in the post-reform period. Research in International Business and Finance, 30, pp.268-283.

Lestari, H.S., 2018. Determinants of corporate dividend policy in Indonesia. In IOP Conference Series: Earth and Environmental Science. IOP Publishing, 106 (1), pp. 1-7

Lintner, J., 1962. Dividends, earnings, leverage, stock prices and the supply of capital to corporations. The review of Economics and Statistics, pp.243-269.

Makochekanwa, A., 2007. A Dynamic enquiry into the causes of hyperinflation in Zimbabwe, University of Pretoria, Working Paper 2007-10.

Mambo, M. (2012). Relationship between inflation and dividend payout for companies listed at the Nairobi Securities Exchange, Master Thesis. University of Nairobi

Mandizha, B., 2014. Inflation and Exchange Rate Depreciation: A Granger Causality Test at the Naissance of Zimbabwe's Infamous Hyperinflation (2001-2005)'. Economics and Finance Review, 3(9), pp.22-42.

Michaely, R. and Roberts, M.R., 2012. Corporate dividend policies: Lessons from private firms. The Review of Financial Studies, 25(3), pp.711-746.

Mirbagherijam, M., 2014. Asymmetric Effect of Inflation on Dividend Policy of Iran's Stocks Market. International Journal of Academic Research in Business and Social Sciences, 4(2), pp.337-350.

Mirza, H.H. and Azfa, T., 2010. Ownership structure and cash flows as determinants of corporate dividend policy in Pakistan. International Business Research, 3(3), pp.210-221.

Mohsin, H.M. and Ashraf, M.S., 2011. Monetary policy restriction and dividend behavior of Pakistani firms: an empirical analysis. Munich Personal Research Papers for Economics Archive, Paper No. 34052. Online at http://mpra.ub.uni-muenchen.de/34052 [Accessed 16 April 2020]

Morck, R. and Yeung, B., 2005. Dividend taxation and corporate governance. Journal of Economic Perspectives, 19(3), pp.163-180.

Mossadak, A., Fontaine, R. and Khemakhem, H., 2016. The relationship between ownership structure and dividend policy in an emerging market: A Moroccan study. Universal Journal of Accounting and Finance, 4(2), pp.89-95.

Mutenheri, E. (2003). The determinants of corporate financial policy in Zimbabwe: Empirical evidence from company panel data (Doctoral dissertation). Loughborough University.

Nguyen, K, T., Le, V, T., Duong, T, T, A. and Hoang, T, N., 2013. Determinants of Dividends payments of NonFinancial Listed Companies in Ho Chi Mihn Stock Exchange', VNU Journal of Economics and Business, 29(5), pp. 16-33.

Njanike, K., Katsuro, P. and Mudzura, M. 2009. Factors Influencing the Zimbabwe Stock Exchange Performance (2002-2007). Annals of the University of Petrosani, Economics, 9(2), pp. 161-172.

Nor, M.I., 2012. The Effect of Dollarization on Developing Economies: Lessons from Somalia's Informal Market Academic Research International, 2(3), 591-597

Pandey, I.M. and Bhat, R., 2007. Dividend behaviour of Indian companies under monetary policy restrictions. Managerial Finance. 33(1), pp. 14-25.

Reyna, J.M.S.M., 2017. Ownership structure and its effect on dividend policy in the Mexican context. Accounting and Administration, 62(4), pp.1199-1213.

Rizqia, D.A. and Sumiati, S.A., 2013. Effect of managerial ownership, financial leverage, profitability, firm size, and investment opportunity on dividend policy and firm value. Research Journal of Finance and Accounting, 4(11), pp.120-130. 
Seida, J.A., 2002. Evidence of tax-clientele-related trading following dividend increases. Journal of the American Taxation Association, 24(1), pp. 1-21.

Sikwila, M.N., 2013. Dollarization and the Zimbabwe's Economy. Journal of Economics and Behavioral Studies, 5(6), pp.398-405.

Tran, Q.T. and Nguyen, T.T.H., 2014. Dividend policy behavior in emerging stock markets: Evidence from Vietnamese stock market. International Journal of Financial Research, 5(4), pp.85-89.

World Bank (2017). The World Bank Data. Available at: http://data.worldbank.org. [Accessed 10 October 2018 ].

Yusof, Y. and Ismail, S., 2016. Determinants of dividend policy of public listed companies in Malaysia. Review of International Business and Strategy, 26(1), pp.88-99.

Zhou, G. and Zvoushe, H., 2012. Public policy making in Zimbabwe: A three decade perspective', International Journal of Humanities and Social Sciences, 2(8), pp. 212-222.

Appendix: Fixed Effects models

\begin{tabular}{|c|c|c|c|c|c|c|c|c|}
\hline & \multicolumn{8}{|c|}{ Table 5: MODEL FOR THE PERIOD 2009-2016 } \\
\hline Variable & 1 & 2 & 3 & 4 & 5 & 6 & 7 & 8 \\
\hline $\mathrm{C}$ & $0.0655^{* *}$ & $0.0645^{* *}$ & $0.0677^{* *}$ & $0.0714^{* * *}$ & $0.0583^{*} *$ & $0.0127 * * *$ & $0.0697 * *$ & $0.0710^{* * *}$ \\
\hline FG & $-0.0010^{* *}$ & & $-0.0011^{*} *$ & $-0.0011^{* * *}$ & $-0.0010^{* *} *$ & $-0.0010^{* * * *}$ & $-0.0011^{*} *$ & $-0.0010^{* *}$ \\
\hline FLEV6 & $0.0016^{*}$ & $0.0016^{* *}$ & & $0.0015^{*}$ & $0.0011^{*}$ & $0.0014^{*}$ & $0.0016^{*}$ & $0.0017^{* *}$ \\
\hline INFLN & 0.0049 & 0.0111 & 0.0041 & & -0.0040 & 0.0134 & 0.0047 & 0.0036 \\
\hline OWN1 & $0.0389 * * *$ & $0.0378 * * *$ & $0.0382 * * *$ & $0.0405 * * *$ & & $0.0386^{* * *} *$ & $0.0431 * * *$ & $0.0385 * * *$ \\
\hline SIZE2 & $-0.0029^{*}$ & $-0.0028^{*}$ & $-0.0030^{*}$ & $-0.0033^{*} *$ & $-0.0026^{*}$ & & $-0.0031^{*}$ & $-0.0032^{* *}$ \\
\hline MSP & 0.0029 & 0.0003 & 0.0011 & 0.0029 & 0.0035 & 0.0007 & 0.0022 & 0.0026 \\
\hline EPS & $0.0492^{*}$ & $0.0493^{*}$ & $0.0452^{*}$ & $0.0421^{*}$ & $0.0698^{*}$ & $0.0536^{* *}$ & & $0.0492^{*}$ \\
\hline $\mathrm{TP}$ & 0.0033 & 0.0013 & 0.0045 & 0.0011 & 0.0026 & 0.0044 & 0.0036 & \\
\hline INV1 & $0.0042^{*} *$ & $0.0040^{* * *}$ & $0.0035^{* *}$ & $0.0037^{* *}$ & $0.0022^{*} *$ & 0.0030** & $0.0045^{*} *$ & $0.0043^{* *}$ \\
\hline OWN5 & $0.0046^{* *}$ & $0.0049^{* * * *}$ & $0.0050^{* * * *}$ & $0.0051 * * *$ & 0.0098*** & $0.0050^{* * * *}$ & $0.0051 * * *$ & $0.0047 * *$ \\
\hline $\mathrm{R}^{2}$ & 0.83 & 0.83 & 0.82 & 0.83 & 0.82 & 0.83 & 0.82 & 0.83 \\
\hline Adj $R^{2}$ & 0.80 & 0.80 & 0.79 & 0.80 & 0.79 & 0.80 & 0.79 & 0.80 \\
\hline F-Test & 24.83 *** & $26.40^{* * * *}$ & $24.48^{* * * *}$ & 25.39 **** & $23.98 * * *$ & $25.90^{* * * *}$ & $24.67 * * *$ & $25.61^{* * * *}$ \\
\hline DW & 2.02 & 2.03 & 2.00 & 2.02 & 1.95 & 2.02 & 2.05 & 2.03 \\
\hline Obs & 239 & 239 & 239 & 239 & 239 & 239 & 239 & 239 \\
\hline
\end{tabular}

*** significant at 1\%; ** significant at 5\%; *ignificant at $10 \%$

The models are estimated using FE and with robust standard errors. The first model contains all explanatory variables which are removed one at a time to check for robustness. The results remain fairly stable for all models.

\begin{tabular}{|c|c|c|c|c|c|c|c|c|}
\hline & \multicolumn{8}{|c|}{ Table 6: MODEL FOR THE PERIOD 2000-2008 } \\
\hline Variable & 1 & 2 & 3 & 4 & 5 & 6 & 7 & 8 \\
\hline FG & $-0.0021 * * *$ & & $-0.0023 * * *$ & $-0.0019^{* * *}$ & $-0.0022^{* * *} *$ & $-0.0021^{* * *}$ & $-0.0024 * * *$ & $-0.0008 * *$ \\
\hline INFLN & $-5.03 \mathrm{E}-10$ & $-5.18 \mathrm{E}-10$ & $-6.59 \mathrm{E}-10$ & & $-5.24 \mathrm{E}-10$ & $-5.02 \mathrm{E}-10$ & $-4.33 \mathrm{E}-10$ & $-3.65 \mathrm{E}-10$ \\
\hline OWN1 & $0.0505 * * *$ & $0.0526 * * *$ & $0.0504 * * *$ & $0.0506 * * *$ & & $0.0487 * * *$ & $0.0509 * * *$ & $0.0529 * * *$ \\
\hline SIZE2 & -0.0012 & -0.0009 & -0.0012 & -0.0013 & -0.0007 & & -0.0006 & -0.0012 \\
\hline $\mathrm{TP}$ & $0.0173 * * *$ & $0.0125 * * *$ & $0.0184 * * *$ & 0.0145 **** & $0.0207 * * * *$ & $0.0185 * * *$ & $0.0141 * * *$ & \\
\hline INV1 & 0.0016 & 0.0011 & 0.0014 & 0.0020 & 0.0016 & 0.0012 & 0.0015 & 0.0017 \\
\hline OWN5 & $-0.0037^{*}$ & $-0.0046^{* * *}$ & $-0.0034^{*}$ & $-0.0038^{*} *$ & $-0.0017^{*}$ & $-0.0036^{*}$ & $-0.0036^{*}$ & $-0.0047 * *$ \\
\hline $\mathrm{R}^{2}$ & 0.79 & 0.79 & 0.78 & 0.83 & 0.76 & 0.80 & 0.78 & 0.78 \\
\hline Adj R ${ }^{2}$ & 0.75 & 0.76 & 0.75 & 0.80 & 0.72 & 0.77 & 0.75 & 0.74 \\
\hline
\end{tabular}

*** significant at $1 \%$;** significant at $5 \%$; *ignificant at $10 \%$

The models are estimated using FE and with robust standard errors. The first model contains all explanatory variables which are removed one at a time to check for robustness. The results remain fairly stable for all models. 